\title{
Computer literacy and level of proficiency in database management system of Polillo District: Basis for computer literacy program for teachers
}

\author{
Bosque, Jilky I. \\ Emilio Aguinaldo College, Philippine (Jnibosque.mnl@eac.edu.ph)
}

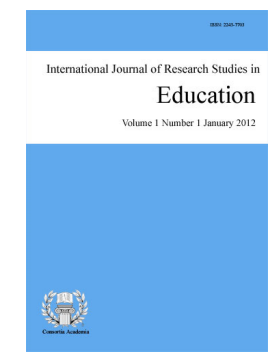

ISSN: 2243-7703

Received: 30 March 2021

Revised: 14 May 2021 DOI: $10.5861 /$ ijrse.2021.652

Accepted: 30 May 2021

OPEN ACCESS

\section{Abstract}

Computer literacy and level of proficiency in database management system of Polillo District teachers during the SY 2016-2017 was identified in this study. The study was composed of 182 elementary teachers from Polillo District. Descriptive-correlational research type of research was used in this study to find out the significant relationship between the teachers' computer literacy and their profile and between the computer literacy and level of proficiency on database management system. Survey questionnaire was the main data gathering instrument. The data were consolidated treated and analyzed using appropriate statistical tools. Results of the study revealed that majority of the teacher-respondents were 40-49 years old; mostly female; with 1 to 5 years teaching experience; bachelor's degree graduate with masteral units; with 6-8 subjects taught; and have their own laptops/computers. In terms of basic operations, computer application, electronic communication, the computer literacy level of the teacher-respondents was rated fairly which means they can perform basic tasks. Their proficiency level in database management system was rated basic meaning they can perform the basic task. The findings of the study served as basis for designing the computer literacy program for teachers in the district. The study further revealed that the younger the respondents are and the shorter their years in teaching are, the better their computer literacy level. Likewise, the teachers who were computer literate were also proficient in database management system. This research allowed the researcher to design Computer literacy program for teachers.

Keywords: computer literacy; database management system; computer applications; computer literacy program; learner information system; teacher information system 


\section{Computer literacy and level of proficiency in database management system of Polillo District: Basis for computer literacy program for teachers}

\section{Introduction}

There is a familiar saying which goes, "nothing is permanent except change." To adapt and manage to these changes, the field of education in the Philippines, especially teachers and educators, is required to study the use and application of new technologies to improve their competency and effectiveness in performing their duties and professional development. It is necessary, therefore, that the teacher should master the basic use of the Computer.

The Department of Education launched the DepEd Computerization Program (DCP) in 2010. Polillo District was lucky to be chosen as the recipient of the said program. One of the objectives of this program is to raise the ICT literacy of learners, teachers, and school heads. Today, 17 schools out of 20 schools in Polillo District have computer sets in school from DCP. However, despite having computers in schools, the most pressing problems are the lack of financial resources for the maintenance of computer and internet connectivity, inability of teachers to know how to use the Computer effectively, and difficulty in integrating Computer in teaching since teachers have insufficient training and experience with the use of the Computer (McPherson, 2011). Moreover, relatively, computer subjects or ICT in the K-12 curriculum are integrated into the EPP subject, which is difficult for some computer illiterate teachers.

In 2013, Polillo District teachers had informal basic computer training during their in-service training conducted in two days. It was the first and last training conducted within the district. Currently, most of the teachers in Polillo District have laptops, personal computers, and computers set in schools to make their duties and responsibility in terms of stabilizing records, encoding information of learners, computation of grades, and browsing the internet. In addition, some teachers study for their master's degree and doctor's degree and prepare their reports and assignments and submit requirements using the Computer and the internet. Unfortunately, based on the researchers' observation and as district ICT coordinator, some of the teachers have marginal computer literacy despite the complete equipment and facilities provided by the DepEd through the DepEd Computerization Program (DCP).

\subsection{Research Questions}

The study's primary aim was to identify the level of computer literacy of the teachers in Polillo District and their level of proficiency in the data management system. Results were used as the basis for the district computer literacy program. Specifically, the study sought to answer the following questions:

1. What is the profile of the respondent teachers in terms of: age; sex; length of service; educational attainment; number of subject/s taught; computer ownership; and the number of years of being a computer user?

2. What is the computer literacy level of the respondents in the following areas: basic computer operations; computer application; and electronic communications?

3. What is the level of proficiency of teachers in Data Management System in the following areas: Learner Information System and Teachers' Information System?

4. Is there a significant relationship between the respondents' computer literacy level and their profile?

5. Is there a significant relationship between the respondents' computer literacy level and their level of proficiency in database management systems? 


\subsection{Brief review of related literature and studies}

Computer literacy - In the study of Roson (2015), she defined computer literacy as the teachers' level of knowledge and skills about using computers in teaching. Literacy is the learning and mastering of symbols and the ability to interpret them. This point of view suggests that computer literacy relates to a basic understanding of how the Computer works. The study concluded that the teachers in Hen. Pio Del Pilar Elementary School was fairly literate in basic operations. However, there is a need to conduct in-service training on basic computer operations and software applications to equip them with the computer skills they will need in using ICT facilities and tools in teaching. These corpora strengthen the desire of the researcher to identify whether Polillo District has the same predicament and, if such is the case, what may be done to address the problem. The works of Akhtar (2010), Censon (2012), Roson (2015) also suggested plans and policies in the training of teachers on ICT, which can be used for the proposal of the program.

Basic computer operations - The study of Dollado (2002), as cited in Roson (2015), showed that teachers and administrators of Calbayog Pilot Central School have minor knowledge in computers in terms of concepts. Moreover, they lacked training in terms of computer use. In line with this, the Municipality of Villasis, Pangasinan, conducted training about Basic Computer Operation and Hardware Servicing. The seminar aimed to refresh and enhance computer skills in the computation of grades and make PowerPoint presentations. Skills training is one of the requirements for teacher-applicants at the Department of Education (http://villasis.gov.ph/ index.php/teacher-applicants-complete-basic-computer-operations-and-hardware-servicing-seminar, para. 1).

Basic computer applications - At present, the Department of Education aims to fully train administrators, teachers, and support staff in word processing, electronic spreadsheet, and graphic software to aid them in their instructional task (Manzano, 2002). Olaolu, Adbulrahaman, and Habibatu (2012) opined that computer application packages such as Microsoft Word could be used to prepare reports, letters, and textual documents. A word processor is used for manipulating text-based documents. Word processing has become the most commonly used software in education (Robleyr \& Doering, 2010). The teachers in the Polillo district commonly use Microsoft word in preparing school reports, teacher and learners' documents, and preparing activity sheets for learners. From this action, the researcher is eager to identify teachers' level of computer literacy in basic computer applications aligned to word processing.

Spreadsheet programs are in widespread use in the classroom at all levels of education (Robleyr \& Doering, 2010). The teachers in Polillo District commonly use Microsoft Excel as an example of a spreadsheet program in preparing and computing grades of learners like an electronic class record, periodical test results, oral and silent reading, encoding nutritional status, making graphs, and others related to computation. Based on these, the researcher is keen to identify teachers' level of computer literacy in basic computer applications align to the spreadsheet.

According to Good (2008), presentation graphics application software is typically used to create a presentation in the form of slides that can be used to create overhead transparencies or printed handouts or books and present information in electronic form. The teachers in Polillo District commonly use graphics like Microsoft Powerpoint and Prezi in preparing and presenting their reports like a lesson and school/study reports. From this observable action, the researcher was compelled to identify teachers' level of computer literacy in basic computer applications aligned to graphics.

The internet offers research, tips, lesson plans, discussion opportunities, and a treasure trove of data (Depaul, 2002). Teachers can find an almost unlimited number of ideas and plans on the internet (Hunt, 2009). Also, Dulan (2010) said that an internet connection would help get people to use computers more for research and send emails to teachers. Teachers also use the internet for communication purposes with students and other peers. In line with this, the Department of Education launched its Program about DepEd Internet Connectivity Program. Luckily, only one school, Polillo Central Elementary School, availed this kind of program due to the kind of school category. 
Mostly, the reports are urgent, due date, and rush, so the main solution to cope with the school reports is to send via email without waiting for the liaison officer to travel and submit the hard copy in the division office.

Database management system - Rouse (2015) defined a database management system (DBMS) as the system software for creating and managing databases. The DBMS provides users and programmers with a systematic way to create, retrieve, update, and manage data. This discussion on database management systems is relevant to the present study because it identified the level of proficiency in the district's database management system. According to DepEd Press Release (2015), LIS is an innovative tool that the Department uses to manage information to promote transparency, informed decision making, and empowerment at different levels of the organization. This system is envisioned to allow the Department better to track its learners in formal and non-formal instruction so that more appropriate interventions can be formulated to provide quality education for all Filipino learners.LIS has allowed the Department to generate the total public school enrolment based on the actual registration of learners (DepEd Order No. 67 s. 2011 and No. 22, s. 2012). This system has a great impact on the researcher's study because she wanted to identify the proficiency of teachers in LIS in enrolling and updating the learners' data.

On the other hand, Cosidon (2016) developed a Student Information System that provided greater satisfaction to the users than the existing system for efficient querying of student information records, keeping the student records more securely. And giving more reliable information records of students on the Kalinga State University Rizal campus. This is similar to the learner information system established by the DepEd in securing learners' data, reliable and updated information of the learner. As stated in Division of Quezon Memorandum No. 42 Memorandum Series of 2016, Quezon Teachers Information System (QTIS) is a web-based solution/database which will serve as the central repository of all DepEd personnel's data. Designed to improve the efficiency of the DepEd Division of Quezon, the system generates personnel information, benefits (loyalty, step increment, bonuses, etc.), and employment status, including promotion, transfer, and retirement. In addition, the system helps manage and automate records that will be beneficial not only to teachers but also to the organization.

Currently, all Quezonian teachers are required to account in the teachers' information system provided by the Division of Quezon because it is the part of human resource information of teachers in the division to encode and update the data of each teacher. The Zonal Education Office, a governmental service organization, developed Teacher Information System, which system would be useful to run the organization efficiently and take a management decision on time (Vickneshwaran, 2012). This kind of system is similar to the TIS of the Division of Quezon, which inspired the researcher to determine the proficiency of teachers in the database management system.

\section{Methodology}

The study aimed to analyze the computer literacy and level of proficiency in the database management system of teachers as the basis for a computer literacy program. Therefore, the study was descriptive-correlational research. The study used all elementary school teachers in Polillo District, composed of 182 teachers who perform the LIS and QPIS and use the Computer in school reports, update data of learners and teachers, study, lesson planning, and present their lesson from twenty (20) schools. The study used complete enumeration in choosing the respondents of this study. Therefore, all teachers were considered as respondents who were part of the survey.

\subsection{Research instrumentation}

Since the study sought to identify teachers' computer literacy and level of proficiency, the survey questionnaire was used in gathering data. The researcher modified the questionnaire used in Roson's (2015) study wherein Part 1 and Part 2 of the questionnaire were adopted while Part 3 was made by the researcher. The first part dealt with the demographic profile of the respondents, which included age, sex, length of service, educational attainment, subject taught, computer ownership, and the number of years of being a computer user. 
The second part assessed the computer literacy of teachers in basic computer operations (performing elementary tasks, manipulating files, using the keyboard for data and program entry), computer applications which are composed of 1) word processor (performing basic word processing tasks, performing editing tasks, performing formatting tasks, and creating reference and citations), 2) spreadsheet (performing data entry tasks, performing editing and formatting tasks), 3) graphics (creating and manipulating graphic files), and 4) electronic communication (using the email/Gmail and using the internet). A Likert-type scale was used in measuring literacy level.

The third part was the level of proficiency of teachers in a database management system which is composed of the following: (1) Learners Information System (performing basic enrolling and editing tasks) and (2) Teacher Information System (creating, manipulating accounts, and editing/updating tasks). Again, a Likert-type scale was used in measuring literacy level.

\subsection{Statistical treatment of data}

The study employed descriptive-correlational research and utilized the questionnaire as a data-gathering tool to draw relevant data and information needed to answer the problems. The data gathered by the researcher were treated statistically using the most appropriate statistical tools. Frequency distribution and percentage were used in assessing the demographic profile of the respondents. Weighted Mean was used to identify teachers' computer literacy and level of proficiency on the database management systems. Spearman Rho and chi-square were used to identify the significant relationship between computer literacy and their profile. Spearman Rho was also used to identify the significant relationship between computer literacy and database management systems.

\section{Results and discussions}

\subsection{Profile of the respondents}

\section{Table 1}

Demographic Profile of the Respondents

\begin{tabular}{|c|c|c|c|}
\hline Profile & Details & $\mathrm{f}$ & $\%$ \\
\hline Age & $20-29$ years & 40 & $22 \%$ \\
\hline Mean Age: 39.66 years & $30-39$ years & 53 & $29.1 \%$ \\
\hline Median Age: $\quad 37.72$ years & $40-49$ years & 56 & $30.8 \%$ \\
\hline \multirow[t]{2}{*}{ Modal Age: 36.87 years } & $50-59$ years & 29 & $15.9 \%$ \\
\hline & 60 years and older & 4 & $2.2 \%$ \\
\hline$\underline{\text { Total }}$ & & $\underline{182}$ & $\underline{100 \%}$ \\
\hline \multirow[t]{2}{*}{ Gender } & Male & 40 & $22 \%$ \\
\hline & Female & 142 & $78 \%$ \\
\hline$\underline{\text { Total }}$ & & $\underline{182}$ & $\underline{100 \%}$ \\
\hline \multirow[t]{5}{*}{ Years in Teaching } & Five years and below & 57 & $31.3 \%$ \\
\hline & $6-10$ years & 42 & $23.1 \%$ \\
\hline & $11-15$ years & 24 & $13.2 \%$ \\
\hline & $16-20$ years & 21 & $11.5 \%$ \\
\hline & Over 20 years & 38 & $20.9 \%$ \\
\hline Total & & $\underline{182}$ & $\underline{100 \%}$ \\
\hline \multirow{5}{*}{ Educational Attainment } & Bachelor's Degree & $\overline{78}$ & $42.9 \%$ \\
\hline & BS with MA units & 91 & $50 \%$ \\
\hline & MA Graduate & 5 & $2.7 \%$ \\
\hline & MA with Doctorate units & 6 & $3.3 \%$ \\
\hline & Doctorate Degree & 2 & $1.1 \%$ \\
\hline Total & & $\underline{182}$ & $\underline{100 \%}$ \\
\hline
\end{tabular}


Bosque, J. I.

Table 1 ...continued

\begin{tabular}{lccc}
\hline \multicolumn{1}{c}{ Profile } & Details & $\mathrm{f}$ & $\%$ \\
\hline No. of Subjects Taught & $0-1$ & 10 & $5.5 \%$ \\
& $2-3$ & 23 & $12.6 \%$ \\
& $4-5$ & 10 & $5.5 \%$ \\
Total & $6-7$ & 69 & $37.9 \%$ \\
Computer Ownership & Eight or more & 69 & $37.9 \%$ \\
& & $\underline{182}$ & $\underline{100 \%}$ \\
Total & Yes & 155 & $85.2 \%$ \\
No. of years of being a computer & No & 27 & $14.8 \%$ \\
user & $0-1$ year & $\underline{182}$ & $100 \%$ \\
& $2-5$ years & 34 & $41.2 \%$ \\
Total & $5-10$ years & 52 & $28.6 \%$ \\
\hline
\end{tabular}

Legend: $f=$ Frequency and $\%=$ Percentage.

Age refers to the biological number of the existence of teachers since birth. The scenario mentioned above is illustrated in a study by Roson (2015) where the majority of the respondent-teachers were 30-49 years old. This implies that a person grows in age, and his physical health deteriorates but increases his experiences as he grows older. Roson (2015) explained that the distribution of gender could be attributed to conventional gender-based perceptions, with females viewed as more nurturing and caring than males or the feminized nature of the profession. She also indicated that females are more interested in taking education courses than do males. A close examination of the table reveals that the district's teaching force is composed of newly hired and younger teachers who belong to the younger generation. In addition, the National Center for Education Statistics (2010) shows that teachers with fewer years of experience are more likely to use computers in their classes than teachers with more years of experience. Educational attainment is the status of the teacher acquired and completed formal education preparation and teachers' training that is recognized as one of the bases of performance in actual teaching (Villaras, 2013 as cited in Roson, 2015).

The need to increase the number of teachers taking advanced/graduate studies which adhere to the effort of DepEd in encouraging public school teachers to pursue and finish graduate studies to be qualified for the promotion and to seek professional advancement. The consortium program of MSEUF-Lucena City that caters to the Polillo Island teachers to take graduate studies is one program that helps teachers in the island municipalities in terms of professional advancement and their aspirations to be promoted. Most teachers handle six and more subjects requiring them to prepare several lesson plans and materials every day. DepEd has always wanted the teachers to be Computer literate. The majority of the teachers believe that owning a computer will help them become more efficient in their school-related tasks. Similar to Robles (2015) study, teachers use their computers in making reports, computing grades of their pupils, and discussing a lesson through PowerPoint presentations. Teachers who have a computer at home do not experience difficulty in accomplishing reports. The teachers maximize the use of the Computer recently since reports, lesson logs, teaching, and learning materials are being encoded and downloaded. Also, DepEd Computerization Program was implemented recently.

\subsection{Level of Computer Literacy of Teachers}

Table 2

Teachers' level of computer literacy

\begin{tabular}{llll}
\hline Variable & Weighted Mean & Descriptive Rating & Rank \\
\hline Basic computer operations & 3.00 & Fairly Literate & 2 \\
Use of Word Processing & 3.16 & Fairly Literate & 1 \\
Use of Spreadsheet & 2.88 & Fairly Literate & 4 \\
Use of Graphics & 2.85 & Fairly Literate & 5 \\
\hline
\end{tabular}


Computer literacy and level of proficiency in database management system of Polillo District

Table 2 ...continued

\begin{tabular}{llll}
\hline Variable & Weighted Mean & Descriptive Rating & Rank \\
\hline Use of Email & 2.83 & Fairly Literate & 6 \\
Use of Internet & 2.95 & Fairly Literate & 3 \\
\hline
\end{tabular}

Legend : Min = Minimum, Max = Maximum, WM = Weighted Mean, and DR = Descriptive Rating.

$4.21-5.00=$ Highly Literate, $3.41-4.20=$ Generally Literate, $2.61-3.40=$ Fairly Literate, $1.81-2.60=$ Hardly Literate, and $1.00-1.80=$ Not Literate.

Teachers perform the basic tasks in word processing. Among the computer applications, word processing is used regularly in preparing a lesson plan, reports/ documentation, and making activity cards for the learners. It reveals that the teachers are competent in handling word processing, and integration of word processing activity is also utilized (Robles, 2015). Even though DepEd requires teachers to have a DepEd email account, not all teachers regularly open their email or never at all, and they forget their password. Similar to Robles (2015) study, the general communication skills of teachers are developed to a basic extent. This means that the extent of the teachers' familiarity and understanding of tasks relevant to emails is very minimal. However, teachers are aware of the importance of email addresses for communication, and DepEd requires all teachers to have an email account using @deped.gov.ph. Still, sadly, this awareness is not put into use because they only have basic skills in performing tasks related to electronic mailing and need more training to perform all the tasks.

\subsection{Level of proficiency of teachers in database management system}

\section{Table 3}

Summary of teachers' level of proficiency in database management system

\begin{tabular}{ccc}
\hline Variable & General Weighted Mean & Descriptive rating \\
\hline Learner Information System & 3.07 & Basic \\
Teacher Information System & 3.00 & Basic \\
\hline
\end{tabular}

Legend: $4.21-5.00=$ Highly Proficient, $3.41-4.20=$ Proficient, $2.61-3.40=$ Basic, $1.81-2.60=$ Below Basic, and $1.00-1.80=$ Not Proficient.

Teachers are more basically skilled in LIS because every year, DepEd produces and gives almost three memoranda about LIS, which are Beginning of School Year (BOSY), End of School Year (EOSY). It includes housekeeping of learners for accuracy, updated information of the learners, and better decision-making and planning of school heads and division planning. Compared to the TIS, DepEd Quezon produces and gives a memorandum to update teacher's information once a year since teachers are promoted, transferred, and hired in a year only. From this result, teachers need more training about the teacher information system for the accuracy, validity, and reliability of their personal information.

\section{Table 4}

Correlation and association analysis between computer literacy level and demographics of the respondents

\begin{tabular}{|c|c|c|c|c|}
\hline Variables & Test Performed & $\begin{array}{l}\text { Statistic- value, and } \\
\text { Sig-value }\end{array}$ & Decision & Conclusion \\
\hline $\begin{array}{l}\text { Computer Literacy Level and } \\
\text { Age }\end{array}$ & $\begin{array}{l}\text { Spearman Rho } \\
\text { Correlation }\end{array}$ & $\begin{array}{c}r=-0.33 \\
p \text { value }=0.000\end{array}$ & Reject Ho & Significant \\
\hline $\begin{array}{l}\text { Computer Literacy Level and } \\
\text { Sex }\end{array}$ & Chi-Square & $\begin{array}{c}\text { Chi-Square } 6.385 \\
\text { p-value }=0.172\end{array}$ & Accept Ho & Not Significant \\
\hline $\begin{array}{l}\text { Computer Literacy Level and } \\
\text { Years in Teaching }\end{array}$ & $\begin{array}{l}\text { Spearman Rho } \\
\text { Correlation }\end{array}$ & $\begin{array}{c}r=-0.289 \\
p \text {-value }=0.000\end{array}$ & Reject Ho & Significant \\
\hline $\begin{array}{l}\text { Computer Literacy Level and } \\
\text { Education }\end{array}$ & $\begin{array}{l}\text { Spearman Rho } \\
\text { Correlation }\end{array}$ & $\begin{array}{c}r=0.037 \\
\text { p-value }=0.621\end{array}$ & Accept Ho & Not Significant \\
\hline $\begin{array}{l}\text { Computer Literacy Level and } \\
\text { Number of Subjects Taught }\end{array}$ & $\begin{array}{l}\text { Spearman Rho } \\
\text { Correlation }\end{array}$ & $\begin{array}{c}r=0.217 \\
\text { p-value }=0.381\end{array}$ & Accept Ho & Not Significant \\
\hline $\begin{array}{l}\text { Computer Literacy and } \\
\text { Computer Ownership }\end{array}$ & Chi-Square & $\begin{array}{c}\text { Chi-Square }=17.121 \\
\text { P-value }=0.000\end{array}$ & Reject Ho & Significant \\
\hline $\begin{array}{l}\text { Computer Literacy Level and } \\
\text { Years of using Computer }\end{array}$ & $\begin{array}{l}\text { Spearman Rho } \\
\text { Correlation }\end{array}$ & $\begin{array}{c}r=0.375 \\
\text { p-value }=0.000\end{array}$ & Reject Ho & Significant \\
\hline
\end{tabular}


The data establish that "computer literacy level" is significantly related to age, years in teaching, years in using the Computer, and computer ownership. Further scrutiny of the values reveals that the relationship between computer literacy level is inversely related to both age and years in teaching. This implies that the younger the respondents are, having a computer, and the shorter their years in teaching are, the better their computer literacy level. While there is a direct relationship between computer literacy level and years in using the Computer, which would imply that the longer their years of using the Computer, the better is their computer literacy level.

This is observable in the situation of Polillo District, wherein the teachers who have a computer, younger teachers, and newly hired teachers have a better computer literacy level because they are in the computer generation. Also, most are assigned to do school reports/documents and serve as a school ICT coordinator. Therefore, they are exposed to using a computer through reporting, assignments, projects, and have a computer subject since college or even high school. Meanwhile, the rest of the sex, education, and subject taught variables were neither related nor associated. This implies that there are no requirements in learning the Computer and developing the computer literacy level of teachers. Therefore, there are no hindrances for the teachers who want to learn professionally.

\section{Table 5}

Correlation analysis between computer literacy level and proficiency level in database management system

\begin{tabular}{llclc}
\hline \multicolumn{1}{c}{ Variables } & Test Performed & $\begin{array}{c}\text { Statistic- value, and } \\
\text { Sig-value }\end{array}$ & Decision & Conclusion \\
\hline $\begin{array}{l}\text { Computer Literacy Level and } \\
\text { Proficiency level in database }\end{array}$ & $\begin{array}{c}\text { Spearman Rho } \\
\text { Correlation }\end{array}$ & $\begin{array}{c}\mathrm{r}=0.709 \\
\mathrm{p} \text { value }=0.000\end{array}$ & Reject Ho & Significant \\
management system & $\begin{array}{ll}\text { Legend: } \alpha=0.05 . r=\text { spearman rho. } 0.80-1.0=\text { very strong, } 0.60-0.79=\text { strong, } \\
-0.59=\text { moderate. } \quad 0.20-0.39=\text { weak. } 0.00-0.19=\text { very weak. }\end{array}$ & &
\end{tabular}

The computed r-value gives an interpretation that there is a strong positive correlation between the respondents' level of computer literacy and proficiency in the database management systems. This implies that teachers who are Computer literate were also proficient in database management systems. There is no reason for the teachers not to perform their duties and responsibilities since they are literate in computers and proficient in the database management system. It also points out that teachers are not left behind in using the Computer and database management system today, and they try to embrace the kind of education today.

\section{Conclusions}

Based on the preceding results, the following conclusions are drawn:

1. The majority of the respondents belonged to the middle age, mostly female, newly hired and younger in teaching, with master's degree, teach with a full load, and have their Computer and almost 2-5 years of being computer user.

2. The respondents have basic computer skills in word processing which connotes basic computer literacy level.

3. The respondents possess primary skills in using the Learner Information System.

4. Computer literacy correlates to the profile of the respondents except on sex, educational attainment, and subject taught.

5. There is a strong positive correlation between the level of computer literacy and the level of proficiency in the database management system of the respondents.

Given the conclusions as mentioned above, the following recommendations are as a result of this offered: 
1. If possible, a customized computer LAC Session should be designed to suit the needs of seasoned teachers or highly technologically challenged teachers.

2. There is a need to conduct a LAC Session on basic operations, word processing, spreadsheet, graphics, email, and the internet to equip teachers with computer operations and applications skills.

3. A collaborated computer literacy program in every school must be implemented to cater to the needs of the teachers in terms of Learners and Teachers' information systems.

4. LAC Session that will update computer literacy and proficiency in database management systems should be the regular pursuit of every school.

5. The Department of Education may consider replicating this study on a national scope to develop a national training or retooling program for teachers, especially on the use of ICT in teaching.

\section{References}

Akhtar, S. (2010). Digital review of Asia Pacific 2009-2010. India: Sage Publications.

Censon, W.W. (2012). Computer literacy program (Unpublished master's thesis). Immaculate Conception College, Nueva Ecija, Philippines.

Cosidon, E.B. (2016). Student information system for Kalinga State University-Rizal campus. International Journal of Management and Commerce Innovations, 4(1), 330-335.

Department of Education. (2015). DepEd LIS, information for greater access to education. Retrieved from http://www.deped.gov.ph/press-releases/deped-lis-information-greater-access-education

Depaul, A. (2002). Survival guide for new teachers. Retrieved from http://eric.ed.gov/?.id= ED442791

Dulan, S. (2010). McGraw-Hill ACT (2011 ed.). USA: The McGraw-Hill Companies.

Good, L. (2008). Teaching and learning with digital photography: Tips and tools for early childhood classrooms. United States of America: Sage Publication.

Halimuran, R.P. (2013). Computer literacy of teachers: Its relation to the students' academic performance in public secondary schools of Payao District (Unpublished master's thesis). Mindanao State University, Mindanao, Philippines.

McPherson, F. (2011). Using computers in schools. Retrieved from http://www.mempowered.com/children/using-computers-schools

Olaolu, A., Adbulrahaman, R., \& Habibatu, R. (2012). Computer literacy and teacher job effectiveness in Kwara State Secondary School. Academic Research International, 2(3), 3-40.

Roblyer, M., \& Doering, M. (2010). Findings on Facebook in higher education: A comparison of college faculty and student uses and perceptions of social networking sites. Internet and Higher Education, 13(3), 134-140. https://doi.org/10.1016/j.iheduc.2010.03.002

Roson, S.R (2015). Computer literacy of teachers as a basis for developing a training design in teachers' whiteboard in Hen. Pio Elementary School, DepEd, Makati (Unpublished master's thesis). Technological University of the Philippines, Manila, Philippines.

Rouse, M. (2015). Database management system. Retrieved from http://searchsqlserver.techtarget.com/definition/database-management-system

Vickneshwaran, R. (2012). Teachers' information system for Paddiruppu education zone. Retrieved from http://ir.lib.seu.ac.lk/handle/123456789/513 
Bosque, J. I.

140 Consortia Academia Publishing (A partner of Network of Professional Researchers and Educators) 